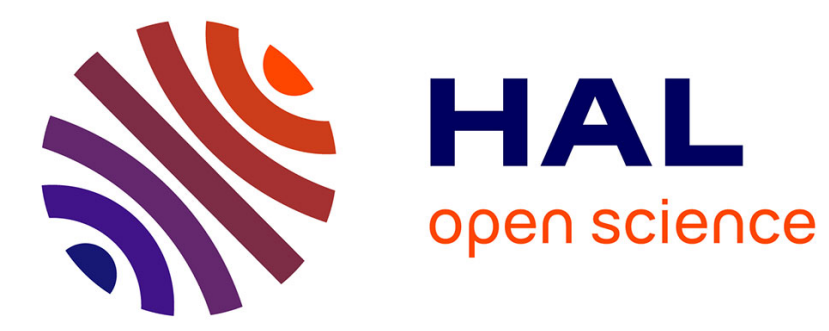

\title{
Can Schools Dispense with Standard Language? Some Unintended Consequences of Introducing Scots in a Scottish Primary School \\ James Costa
}

\section{- To cite this version: \\ James Costa. Can Schools Dispense with Standard Language? Some Unintended Consequences of Introducing Scots in a Scottish Primary School. Journal of Linguistic Anthropology, 2015, 25, pp.25 - 42. 10.1111/jola.12069. halshs-01413277}

\section{HAL Id: halshs-01413277 \\ https://shs.hal.science/halshs-01413277}

Submitted on 9 Dec 2016

HAL is a multi-disciplinary open access archive for the deposit and dissemination of scientific research documents, whether they are published or not. The documents may come from teaching and research institutions in France or abroad, or from public or private research centers.
L'archive ouverte pluridisciplinaire HAL, est destinée au dépôt et à la diffusion de documents scientifiques de niveau recherche, publiés ou non, émanant des établissements d'enseignement et de recherche français ou étrangers, des laboratoires publics ou privés. 


\title{
Anthropology
}

\author{
- James Costa \\ Center for Multilingualism in Society across the Lifespan \\ University of Oslo \\ james.costa@iln.uio.no
}

\section{Can Schools Dispense with Standard Language? Some Unintended Consequences of Introducing Scots in a Scottish Primary School}

\begin{abstract}
This article analyzes some unintended consequences of the introduction of Scots, Scotland's nonstandardized vernacular, in a primary school. I show that the lack of established definition of the language or standardization entails three different processes: first, indexical links are established between Scots and a number of social properties (amusement, lack of seriousness); second, the pupils are othered in a process that constructs them as speakers of Scots; third, that process is completed by the reversal of this latter proposition: what the children speak is Scots (and not English) because of their geographic (and covertly social) origin, locking them in an identity as speakers of nonstandard/substandard language. This analysis allows me to discuss this case in terms of circulation of linguistic authority within the classroom in view of the indeterminacy of a legitimate or generally accepted version of Scots. I conclude by reflecting upon the nature of standard languages, whose status positions them not as just another linguistic variety on a par with others, but as forms of speech whose legitimacy lies not (only) within speakers' identity but within representative institutions, hence their claim to neutrality and inclusiveness, however subverted this may be in reality. [nonstandard, education, Scotland, linguistic authority, legitimate speaker]
\end{abstract}

\section{Introduction: Nonstandard Speech in Education and Issues of Authority}

I gied him a five," said Colin, 11, a pupil of a Primary 7 class in central Scotland. "OK, so you gave him a five. What about you, Kevin?" asked the teacher. "I gived him a six," said Kevin, a boy the same age as Colin. "OK, so you gave him a six, thank you, Kevin," said the teacher. The scene took place in 2008 in a school in central Scotland, both pupils having been asked to evaluate a third boy's work after the autumn break. In that class the pupils were entitled to use Scots, by then viewed by the school authorities (as by the Scottish and United Kingdom governments) as a Germanic language close to English and as the presumed home language of most pupils, a stance only recently adopted. In most Scottish schools, the same elements of speech would be categorized as slang and be instantly corrected by teachers. But in the school in question it was presumed that the general use of Scots in education, as opposed to its traditional banishment, would bolster pupils' confidence and eventually lead to better academic results. The

Journal of Linguistic Anthropology, Vol. 25, Issue 1, pp. 25-42, ISSN 1055-1360, EISSN 1548-1395. (C) 2015 by the American Anthropological Association. All rights reserved. DOI: 10.1111/jola.12069. 
presence of three forms of the preterit in the quoted interaction bears traces of that attempt and raises a number of interesting questions: why are there three forms if two languages are said to be present? Which forms are socially acceptable, and in what settings? Why does the teacher not discuss any of the forms produced by the pupils?

As far as the United Kingdom is concerned, the use of nonstandard language in education seems to have attracted more scholarly attention in the 1970s and 1980s (e.g., Cheshire et al. 1989) than it has recently (see, however, Strachan 2012). In Scotland, from the late 1990s onward, scholars, writers, and language advocates (starting in particular with Niven and Jackson 1998) theorized a new type of approach concerning the teaching of Scots that treats Scots as an independent language (i.e., not a dialect of English) while preserving many features usually associated with dialect, such as the lack of a recognized standard. In the school I observed, one consequence was the type of situation described at the beginning of this article, where socially ratified forms (such as gied) or nonratified ones (gived) coexisted without formal intervention.

In the school where the present study was conducted the pupils were considered free to speak either "English" or "Scots" (the two categories that had official currency) as they wished. English here refers to Standard Scottish English (SSE), defined primarily in terms of phonological features derived from the various Scottish vernacular varieties (McClure 2008:79). In practice, any nonstandard utterance was considered Scots rather than SSE. Nonstandard was defined by the teaching staff according to criteria that were not made explicit, and related to lexical, syntactic as well as phonological features. The reason for this is mainly the absence of a recognized standard for Scots-or for that matter, of a universally accepted definition of Scots. In practice, given many teachers' self-asserted lack of confidence in Scots, this situation amounted to teachers surrendering a large part of their traditional authority in matters of language. Undoubtedly, such situations also occur in other contexts, in particular where emphasis is placed on valorizing languages not ordinarily used at school and where children temporarily take over the teacher's voice (e.g., Billiez and Lambert 2008; Bonacina-Pugh 2013). But the lack of a definition of Scots or of a Scots language community (Costa 2014) and the proximity with English rendered the exercise perilous for the teacher in particular in terms of assessing what might be categorized as a different language vs. what might be a sign of language acquisition problems, a problem long identified in the case of African American Vernacular English (e.g., Labov 1973). In the classroom, during those moments dedicated to Scots (one hour per week in the class under scrutiny here), teacher authority was thus handed over (at least partially) to books, external experts, and also pupils-construed as experts of their language. Many of the interactions between the pupils and the teacher thus consisted in the teacher's attempt to define her pupils as competent and legitimate speakers of Scots in order to reinforce their self-confidence and to enhance their competence in Scots.

In this article, I analyze some of the (unintended) consequences of introducing a lect that has no standard form, usually a prerequisite to formal education, in the everyday activities of an educational institution. In particular, I examine what becomes of the authority traditionally held and exercised by teachers in a context where they are potentially partially or totally divested of it (see also Jaffe 2005). By authority, I mean the ability to command respect and acceptance of one's word as legitimate (Woolard 2008). In educational contexts, authority is usually conveyed by teachers through their social position as well as through the type of language they use. Authoritative language and social position thus mutually reinforce one another. Schools consequently offer models of authority and connect teachers, in both practice and discourse, with legitimate forms of language. The analysis of the introduction of nonstandard language in education is thus revealing of the contemporary workings of standard language. 
The scene at the opening of this article was recorded in 2008 when I spent several weeks doing ethnographic fieldwork in a school in central Scotland for my doctoral thesis. In that school, the academic staff sought to implement a language and literacy program aimed at raising the profile of Scots as a language. The program had been devised by the education branch of a small Scots language publisher, whose aim was both to promote Scots in ways similar to other language advocacy movements in Europe, and to address issues of inequality. The publisher believed that pupils were subjected to schooling in a language that wasn't theirs, namely Standard English, leading to underachievement in terms of literacy skills in particular. As well as underachievement, the priority for the school, located in a working-class and relatively poor area was also to address its recent (unofficial, provided by Scottish newspapers based on government figures) ranking as last in the county in terms of literacy skills. While the current Scottish Curriculum for Excellence (literacy and English) does mention the possibility to pay attention to "dialects," no such guidelines existed at the time of this study.

At the time of my investigation over five hundred primary schools were involved in the program run by the publisher. In the school I observed, I followed two groups in particular: one group of 7- to 8-year-old pupils, and another group consisting of children aged 10 to 11. In this article, I focus on the first one, where the teacher told me she was particularly committed to the Scots language as a result of her own Gaelic family background (unlike Scots, Gaelic is recognized as official in Scotland and is reportedly spoken by less than $2 \%$ of the population according to the 2011 national census). Although she was not, according to her own statement a speaker of Scots herself, she invested in the language in terms of time and dedication, and planned her lessons very carefully combining her prior knowledge of Scots with dictionary work.

I anchor my analyses in a critical sociolinguistic approach to educational settings, connecting an ethnographic approach with attention to the micro-interactional order so as to connect the discursive order of the classroom with wider issues of language ideologies (Jaffe 2005; Saxena and Martin-Jones 2013), in particular in terms of hierarchization of languages and speech forms. Accordingly, I approach education as "a key site for defining legitimate language" as well as "for constructing what counts as knowledge, what counts as displaying knowledge, and who may define and display knowledge" (Heller and Martin-Jones 2001:3). I will also make use of two other tools: first the notion of othering, which I briefly define for now as the discursive, permanent association of a group of meaningful others with certain characteristics (Joseph 2013). I will also refer to the notion of stance, "taking up a position with respect to the form or the content of one's utterance" (Jaffe 2009a). Both notions allow me to take a language ideological approach to analyze one instance in which the definition of the Scottish vernacular as language or dialect does matter for some social actors as one (largely unaddressed) way to perform identity and semiotize otherness in interaction in contemporary Scotland. The attribution of stance vis-à-vis language is a central element in that process, one which assigns the children particular social and linguistic identities.

The data I draw upon here were extracted from one particular class moment designated as a "Scots language hour." The interactional excerpts presented below are representative of the confusion that teachers find themselves in when using or confronted with the usage of Scots. I analyze these excerpts from an interactional sociolinguistic perspective, focusing in particular on how meaning as well as different individual and social positions are negotiated through interaction.

As background, I first provide some evidence about how Scots is construed as a linguistic object in contemporary Scotland, in particular as one that does not require formal standardization. I then show the types of issues and problems that arise when applied to education. I characterize three distinct stages in the processes I observe in 
classrooms: 1. indexical links are established between Scots and a number of social properties; 2 . the pupils are othered in a process that makes them speakers of Scots; 3. that process is made complete by the reversal of this proposition: what they speak is Scots because of their geographic (and covertly social) origin, a process which locks them in an identity as speakers of nonstandard (and maybe substandard) language.

It should be very clear from the outset that this article does not criticize either the Scots language program I analyze or the teacher who generously let me sit in on her classes. It does, however, seek to question practices that are constrained by historical and social choices, in this case the absence of a linguistic standard, and perhaps the lack of desirability thereof and the continuing debate over language hierarchies between "language" and "dialect" in contemporary school regimes in Scotland. In so doing, I seek to understand what it means to introduce linguistic forms in formal settings from which they had previously been excluded and for which adequate instructional terminology and appropriate registers might be not have been developed.

\section{Scots as Unconstrained, Anarchic Language}

There is no apparent consensus as to what Scots is in the way that there is for, say, Gaelic, another language categorized as traditionally spoken in Scotland. The debate as to whether Scots should be considered a dialect of English, an English (or Anglic) dialect or a language in its own right has been rife for decades (if not centuries) and the answer undoubtedly lies in political choice rather than in any type of clear-cut criteria which would settle the argument once and for all. ${ }^{1}$ More relevant to our discussion is the lack of public perception that such a thing as a Scots language exists. A 2010 government-commissioned survey indicated that $85 \%$ of the sample reportedly spoke Scots, while $64 \%$ of that same sample did not view Scots as a language in its own right:

The majority of adults in the sample (64\%) didn't think of Scots as a language, with around half of this group holding this view with conviction ( $34 \%$ of the total sample). However many of those who disagreed $(30 \%)$ did so strongly $(16 \%$ in total) highlighting the absence of any form of consensus on this issue. (TNS-BMRB 2010:15)

According to the national 2011 population census however, around 30\% of the Scottish population declared some level of proficiency in Scots. ${ }^{2}$ Defining Scots has long been a preoccupation in Scotland not least among Scots language advocates. The Scots language movement emerged in the form of a literary Renaissance in the 1920s (Lyall 2014), propelled by writers such as Hugh MacDiarmid and Edwin Muir, and has gone through phases where standardization featured high among the priorities of its proponents (McClure 1980, 1985, 1990; Purves 1997). The current dominant position among language advocates however, including the promoters of the Scots language education program under examination in this article, is that Scots represents a continuum that encompasses the linguistic practices of most of the population of Scotland, from accented SSE to urban and rural dialectal practices. ${ }^{3}$ Iseabail Macleod, coeditor of the Scots Thesaurus (Macleod et al. 1999) and of several other Scots dictionaries, famously declared in a 1997 interview to the Scots Magazine: "Scots covers everything from dialects which the English-or even other Scots-wouldn't understand, to the way we're speaking just now, which is English with a Scottish Accent" (quoted by Dossena 2005:15). Accordingly, the consequence in education is that "[t]he children, the teachers, the parents-everyone knows Scots already. It's just that Scots has never been formally acknowledged in the classroom environment" (Fitt 1998:93).

This assertion provides a rationale for the claim that Scots is the home language of most pupils in Scotland and conversely, that the nonstandard practices of Scot- 
tish children constitute in actual fact the present state of the Scots language. English can accordingly be construed as a language foreign to the pupils, and educational failure can be analyzed as the product of a cultural mismatch between Scotsspeaking children and the English-speaking institution rather than as linguistic deficit, i.e., as the result of inherently poor language skills rooted in social provenance (Collins 1988).

This view leads to the acceptance that there are no definite criteria to establish what counts as Scots and what does not, as well as to the idea that Scots has no standard form and should not have one, at least for the time being. To return to the interaction quoted at the opening of this article this means that the question "Is it Scots or Scottish English with an embedded Scots form?" is of no relevance whatsoever. That interaction could have been semiotically represented as more distinctively Scots had I chosen to write, say, A gied him a fyve instead of I gied him a five but according to the view outlined above the other spelling doesn't make it less Scots.

To complicate matters further, Scots language dictionaries published by the Scottish Language Dictionaries (SND) - an institution which claims to produce purely descriptive work and explicitly rejects prescriptivism (Macleod and Cairns 1993) - include only words that are either different entirely from standard English, or that are found in written texts with spellings that differ from English. This perception that common forms are de facto assigned to English in turn leads to the perception that Scots, if at all a language, is an incomplete one, lacking in terms which for which the English must be used. In fact, linguists have often referred to Scots as a semi-language or Halbsprache (Aitken 1990; Görlach 1996). Standard English is thus implicitly over-valued in the process of constructing Scots as a language.

In the midst of this apparent lack of consensus, several proposals for standards have been put forth but the overall agreement today is that all such initiatives would lead to bitter disputes over which forms should be adopted and how they should be spelled. This, however, does not exclude arguments over the issue. Some, such as David Purves, the former editor of Lallans-an important Scots language literary journal published since 1973 - have actively advocated the use of an orthographic and grammatical standard in education, one which would be coherent, consistent, and recognizable with respect to English (e.g., Purves 2002). Such a move should, according to that view, restore the natural geographic and historical continuity of Scots as the language of the nation and the people. In that model, the language derives its legitimacy and authority from its continued use among the population of Scotland and in literature since the Middle Ages, manifested in the use of indigenous orthographic forms such as <ei $>$ for English <ee $>$ (e.g., $<$ heid $>$ rather than $<$ heed $>$, "head") and $<$ ou $>$ for $<$ oo $>$ (e.g., $<$ droukit $>$ rather than $<$ drookit $>$, "drenched").

The current prevailing view, however, is that Scots can dispense altogether with a standard form (see Costa 2010). James Robertson is a well-known literary figure in Scotland who often makes use of Scots in his novels. In the introduction to an edited collection of short stories in Scots, he writes:

There is a wide variety of approaches in these stories to problems of Scots orthography, and I have not sought to eliminate these. One argument against a standardisation of Scots spelling is that one of the language's very strengths lies in its flexibility and its less-than-respectable status: writers turn to it because it offers a refuge for linguistic individualism, anarchism, nomadism and hedonism. What has often been perceived as a fatal weakness may in fact be the secret of its resilience and survival against four hundred years of creeping Anglicisation. If there are inconsistencies - to adapt Walt Whitman - very well then, there are inconsistencies: the language contains multitudes. (Robertson 1994:xiv)

"Anarchism" and "hedonism," however, have their limits and are by no means universally accepted principles among Scots language advocates. Other sources warn 
the potentially unaware or ill-advised user of Scots that: "If you are using this dictionary to compose Scots texts ensure that you are aware of the correct semantic and grammatical use of words you are unfamiliar with. If you ignore this, what you are writing will not be Scots, but gibberish" (Eagle 2002, emphasis in the original). While the idea of linguistic anarchy (to use Robertson's term) might be appealing, social ratification clearly does not acknowledge any authoritative form of Scots, which blurs the situation in particular for anyone trying to learn Scots. What therefore best characterizes Scots, more than anarchy and certainly more than hedonism, is the reality of subtly covert sociolinguistic rules of language use, as will become obvious from the next section-the risk of "gibberish" looms large.

Practically speaking however, and in educational terms at least, the freedom principle meant (in the cases I observed) that no prescription of any kind should be imposed when it came to Scots: the children should feel free to write Scots in whichever way they saw fit, and would not be evaluated or tested on their Scots language work. The role of Scots was thus both recreational and symbolic in that it would not partake in the traditional forms of evaluation that authenticate important work in contemporary European school regimes. The Scots books used in class did not present uniform models of spelling either: all the contributing writers implemented their own personal choices in terms of spelling and density of Scots-to use McClure's (1979) term. Scots, seen as the children's first language, albeit traditionally scorned and banned from the public space, was to be a refuge for them as pupils, a space of freedom where they could freely experiment with language without fear of normative pressure. Recategorizing the actual nonstandard practices of the children as "Scots language" and consequently promoting them as legitimate was meant to bolster their selfconfidence while avoiding the risk of creating a double diglossic situation potentially caused by the introduction of a standard too different from their everyday speech.

\section{Legitimizing Scots in Education}

The views outlined had far-reaching consequences in terms of how Scots was introduced in the school. As mentioned above, the school's head teacher had contacted a Scots language writer working with a Scots publisher who had developed a program for introducing Scots language literacy as a last resort to improve reportedly very poor literacy skills. Although the central educational county library, in charge of dispatching books to the various schools, had proven supportive of that scheme (investing in Scots language books, for example), the school had no previous experience of involvement with Scots, and had heard of the publisher's initiative through word of mouth. The school itself was located in a working-class area with high levels of unemployment and low levels of income and the alleged wide use of Scots was repeatedly-implicitly and explicitly-correlated with low socioeconomic status.

The introduction of Scots in the school implied an array of actions and decisions: first, the school paid the writer to lead writing classes in Scots for one group once a week over a period of ten weeks. Second, Scots was to be allowed as a legitimate means of expression everywhere in the school, for all pupils. Finally, children's books in Scots were donated by the publisher and placed in every classroom, so that pupils could choose between Scots and English for their reading material. The books could also be borrowed and taken home.

In terms of actual teaching practice, and since children were considered to be speakers of Scots already, the aim was to recategorize existing practices with reference to Scots and English where previously they would have been labeled bad English/ slang vs. correct English. Through an emphasis on reading and writing, the Scots language program also aimed at developing the children's competence in the lan- 
guage, in particular regarding lexis. Consider for example the following instructions from the publisher regarding how teachers should initially introduce Scots to their pupils:

Speak to your class in English and ask them to identify the language you are speaking as English.

Now tell your pupils that you are about to stop speaking in English and that you are going to speak a different language. (Don't at this point use the word Scots.) [...]

Through fun active Scots Language activities like these, pupils will quickly develop an understanding of the differences between English and Scots. How does Scots sound compared to English? Which Scots words do your class particularly like and why?

If you continue to refer to each language using the names English and Scots, you will have two very useful terms with which to progress to teaching Literature in Scots. (Wee Fairy tales, Dominie's Notes, TAG Citizens Theatre \& Itchy Coo, n.d.)

The operation thus aims at assigning various parts of the children's speech to one language or another and to generate an ideal awareness of the coexistence of two languages in their everyday repertoires-in other words, it assumes that all children know Scots, and have some attachment to the forms which will be labeled as Scots. It is built on a further assumption that teachers are themselves able to distinguish between Scots and English, and that both languages are not embedded in hierarchical relations. This raises the question of the legitimate speaker: can schools turn illegitimate dialect speakers into legitimate speakers of a language, Scots, simply by recategorizing their speech from dialect or slang to language? Also, the emphasis is on Scots, not English; but how is their status as speakers of English categorized? Does native speakerhood in Scots imply an L2 competency in English? I will address these questions in the next section by analyzing a series of interactions recorded during a one-hour Scots language class.

\section{Using and Discussing Scots in Class: Staging the Linguistic Conflict}

While the teachers were under no obligation to use Scots themselves, Ms. Brennan, a dedicated teacher in charge of a group of 7- to 8-year-olds thought it important to prepare a class in Scots once a week on the grounds that this was her pupils' language. She related this language ownership to her own connections to the Gaelic-speaking West of Scotland. Her engagement was apparent in the classroom through the presence of a poster designed by the pupils (at the teacher's instigation), which read: "Primary 5 are effectively contributing to keeping the Scots language alive." In that particular instance, the discourse on Scots drew on more habitual discourses about minority languages (and possibly on discourses of language endangerment).

In the session I discuss below, the children have just been presented with two poems to be identified as written in Scots, each one written according to its author's own orthographic principles. While I focus on one only ("Lament for a lost dinner ticket") the other one ("Listen tae the teacher") is worth mentioning since together they both represent forms of conflict caused by the use of Scots in spaces where English is the expected language. This second poem tells of a young boy's experience at school and home: he is scolded for using Scots at the former and English at the latter. The conflict is temporarily solved by the grandfather's advice to know when to use which.

The poem that is the focus of the analysis in this paper depicts a young boy being rebuked for leaving his dinner ticket (allowing him to eat lunch at school) in his pocket. The ticket is destroyed when the trousers go in the washing machine. It is not clear whether the author intended the poem to be "in Scots," or whether she merely sought to capture a vernacular voice (see below). Whatever its author intended the poem to be, and irrespective of what many 
purists might think, the poem is included in several Scots language anthologies designed for school children, not least the Kist/A'Chiste anthology, a collection of Scots and Gaelic texts developed for educational purposes and initially published in 1996. It is now available online on the official Scottish government "Education Scotland" website. ${ }^{4}$

Consider the following extract from the very end of the poem ${ }^{5}$ (my translation/ transliteration), in which the child explains what happened to his ticket:

$\begin{aligned} 1 & \text { They sed wot heppind? } \\ 2 & \text { Nme'nma belly } \\ 3 & \text { Na bedna hospital } \\ 4 & \text { A sed Apititnma } \\ 5 & \text { Pokit an she pititny } \\ 6 & \text { Washnmachine } \\ 7 & \text { They sed Ees thees chaild eb slootly } \\ 8 & \text { non verbal? } \\ 9 & \text { A sed MA BUMSAIR } \\ 10 & \text { Nwen'y sleep! }\end{aligned}$

They said what happened?

And me and my belly

In a bed in a hospital

I said I put it in my

Pocket and she put it in the

Washing machine

They said Is this child absolutely non verbal?

I said My bum's sore

And went to sleep!

The poem uses a number of stylistic devices to represent two distinct voices, the child's voice (lines 1-6 and 9-10) and the one of indeterminate adults ("they," lines 7 and 8), dismayed by the child's language and prompting them to call the child "non verbal" (line 8). In Preston's (1985) terminology, the poem displays examples of allegro speech forms (e.g., Nme'nma belly, line 2, which does not respect usual word boundaries) to represent casual speech, dialect respellings (e.g., "pititny," line 5) in order to capture dialect pronunciations, as well as eye dialect (spellings which emphasize a sense of difference without representing any phonological difference with standard pronunciation, e.g., "sed" or "wot," line 1). Lines 7 and 8 are meant to represent Received Pronunciation, while the rest of the poem represents a nonstandard voice.

David Purves, in the introduction to his Scots Grammar (which he hoped could be used as a model for correct modern Scots grammar and spelling) comments on this particular poem. He writes: "This [type of spelling] has its charms, but the projection of this kind of DIY language as modern Scots, simply perpetuates the notion that Scots is corrupt English" (Purves 2002:7). The syntax of the poem is no different from SSE, and Scottishness is achieved only visually.

Rather than an opposition between two languages, the different language forms indexed by the spellings could just as much be interpreted in terms registers pertaining to different degrees of formality or referring to social origin: indeed, the verse on line 7 can be read as representing a standard or upper-class English (RP) voice, whereas the rest of the poem can be read as an urban, working-class variety of Scots. The allegro speech forms convey an accelerated rhythm supposedly indexical of working-class speech and sloppiness, whereas line 7 detaches every word, and even spells "absolutely" as <eb slootly $>$ (/,æb.s'lu:t.li/), relying on a stereotypical image of RP speech.

In her reading of the poem to the class, the teacher was careful to make this opposition salient. However, she categorizes the occurrences as not as, say, posh vs. working-class speech, but as English vs. Scots:

Excerpt 1

1 Teacher so the way the author has written it in Scots / is the way that / a Scots person would say it / the not adding in a:ll the vowels and / every consonant / how many words how many words can we actually see in that bit there / someone else // Kendall $\uparrow$ 
In the absence of a standard model of Scots, the teacher adopts a stance whereby she claims knowledge of what is Scots and for that purpose draws on two frames. First she uses the language vs. dialect dichotomy, the former representing a model of completeness, the latter a deviation thereof (compared to which letters or sounds are seen to be "missing"). The second frame posits that Scots as a language exemplified in the ordinary speech of Scots people (as expressed by Macleod's in the statement reproduced above). Together, this amounts to saying that it is Scots because it is not English, or at the very least because it is not written conventionally.

As we will see in the next section, the dialect vs. language frame is central to this analysis in that it conditions the entire set of interactions between the pupils and the teacher, one that ends up being resisted by the pupils on the grounds that they too can participate in both types of registers/languages.

\section{The Indexical Consequences of Framing Scots and English as Different Languages}

In the differentiation process the teacher adopts, she defines Scots in contrast to English using a number of oppositions. One meaningful opposition involves the language itself; another involves speakers (her vs. the pupils). The first opposition is exemplified in how she frames her request that the pupils prepare a rendition of what the poem would look and sound like in English:

\section{Excerpt 2}

Teacher put it in language that we would read in reading books in school

The age (and possibly class) opposition featured in the poem is supplemented with the idea that English belongs with books and schools, whereas Scots, by contrast, is the preserve of nonschool and informality. In the next interaction, the teacher again seeks to construct meaningful oppositions between Scots and English, framing the former as fun and the latter, by contrast, as serious. She refers to one of the pupils, Andrew, who had read the poem out loud the previous week.

\section{Excerpt 3}

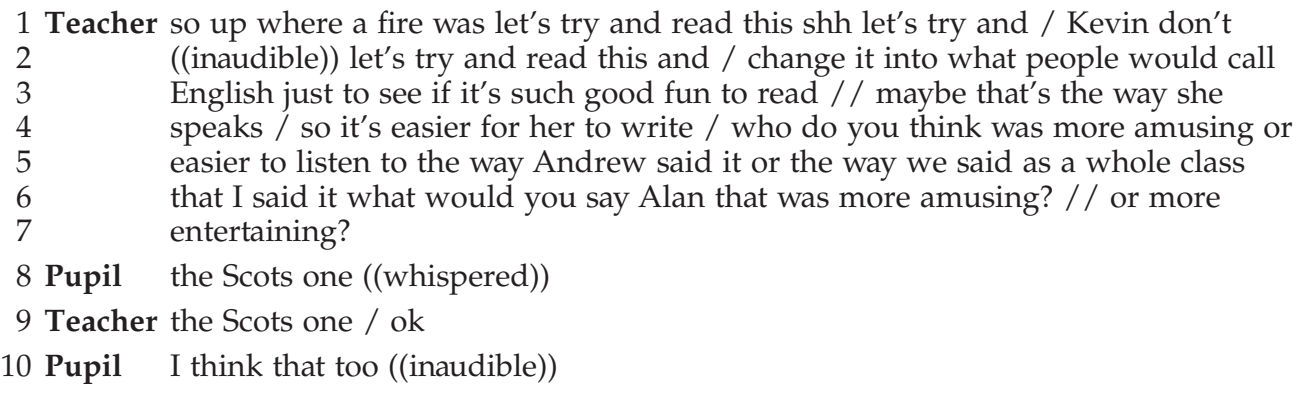

The teacher distances herself from the labels she is trying to establish, namely Scots and English, but apparently only to reinforce Scots as a category connected with fun and pleasure. Note however that since the language of the poem was only called Scots because it was categorized as such in the classroom interaction, the English rendering meant reading the same text with an English accent. The question thus entailed linking Scots and fun as a type of first-order indexicality, but as may be inferred from excerpt 2 another link is also created which connects the pupils with Scots on the one hand and the teacher with English on the other. This, we argue in the next section, effectively amounts to othering the pupils. 


\section{Othering the Pupils}

Othering is an operation that involves singling out a (potentially threatening) Other in a schematic way in order to define boundaries of self (Jaworski and Coupland 2005). Othering is not merely differentiating. While this last operation simply takes note of dissimilitude, "[o]thering, in contrast, occurs when an individual or a group of people is denied a clearly defined status-for example, when an individual or a group is designated as 'anomalous,' 'peculiar,' or 'deviant,' or is objectified, stereotyped, naturalized, or essentialized" (Jaworski and Coupland 2005:672). Consequently, the othering process amounts to being assigned a fixed social position. This definition, however, implies the existence of two very separate, if not different, groups or sets of social actors. I argue that in the case I have described such a process of othering is under way, though not to keep a dangerous Other at bay but rather to act in favor of an Other to be protected-and championed: the children/pupils. The process is, however, much the same: Others are constituted as a quasi-essentialized group with definite homogeneous properties (the children speak Scots). In this particular case one might argue that as the teacher doesn't actually speak Scots, the act of othering might be simply descriptive. However, the lack of definitional criteria meant the teacher too could also have aligned with some form of Scots language competence.

There are nevertheless strong associations between nonstandard speech and childhood, a constant association in the various schools I visited. More generally such practices are perceived as something that parents are wont to extirpate from their progeny. Teenagers I met during interviews at the local secondary school also associated Scots (or "slang" as they called it) with something that was given up after a certain age. While this is questionable, it reinforces the association of "Scots" (along with "slang," or other categorizations of nonstandard practices) and childhood as an act of othering.

Construing pupils as Scots speakers is therefore a two-step operation. It involves first establishing that they speak Scots-unlike the teacher-and second that what they speak naturally is Scots, and only Scots, consequently construed as their natural way of speaking. The first operation can be seen below in the following excerpt:

\section{Excerpt 4}

1 Teacher right a couple of people are saying / do you say washing [wDSn] machine / put 2 your hand up if you say washing [wDSn] machine //// hands down then /

3 who's who pronounces it washing [wa $\int \mathrm{n}$ ] machine

4 Pupil washing [wa nn] ((laughter))

5 Teacher that's not wrong / that's not wrong that is the way you / that is your / native 6 tongue that's the way you're speaking so you say washing [wa $\left.\int \mathrm{n}\right]$ machine

The teacher appears to enact and attribute a mixed stance with respect to Scots, juxtaposing the affective ("that is your native tongue") and the epistemic ("that's not wrong") in lines 5 and 6 . The pupils are construed as the experts of their language, yet the teacher maintains expectations of authenticity regarding the nature of Scots: for want of an authoritative definition of Scots, the discussion focuses on the level of (alleged) Scottishness of the quality of a particular vowel (Scottish [a] vs. English [p]). But more importantly it links the vowel, despite its clear minority status in the classroom, not only with Scottish speech but also with the pupils themselves and construes them as an imagined homogeneous group of Scots speakers. The homogenizing aspect is illustrated seconds later when, not getting the expected pronunciation, the teacher corrects what she understands as hypercorrection:

\section{Excerpt 5}

1 Teacher so you say / kevin you say to me / mrs brennan I put it in my pocket ['pok.It] 
3 Kevin mrs brennan I put $\mathrm{i}(\mathrm{t})$ in my POcke(t) ['ppk.It]

4 Teacher no don't try and / dress $i(t)$

The underlying expectation is that pupils speak Scots, which in turn is linked with a nonstandard (i.e., non-SSE) pronunciation of the word "washing machine." So not only are the children perceived as speaking Scots, but Scots is also attributed the status of their "natural" way of speaking: their expected normal, authentic (i.e., vernacular) speech as an index of their real selves (Coupland 2003). In that sense, the pupils are locked in the teacher's notion that their speech is Scots (or in an imagined version of Scots). The same issue arises in the following excerpt with the same word:

\section{Excerpt 6}

1 Teacher pocket so / how / everyone say it / don't try and say it / pocket / say it to me 2 you say // when I count to three say / po:cki(t) ['pok.tt] po:cke(t) ['pok.et] / 3 whatever way you say it one two three

4 Pupils pocket ((various pronunciations)) //

While the aim is to value the everyday speech of children, in the absence of either a study of their actual everyday speech or of an agreed representation of Scots (a standard) the children are essentialized as speakers of Scots, a variety whose indexical links I have shown to be in fact not-so-desirable even in the context of language valorization implemented in the classroom. Ironically, too, this view forces the teacher to depart from the principle that whatever the children say ought to be considered correct, revealing an underlying representation of Scots as both anything that is not standard English, and yet still defined by a set of linguistic expectations, lexical or phonological. This dual representation remains implicit throughout the Scots hour. What is at play appears to be a typical act of attribution of stance, in which an ideal model of bilingualism is projected onto the children (see Jaffe 2009b for a similar case in a Corsican classroom), one in which children master two distinct codes and are able to distinguish and switch between them. The pupils are viewed as already speaking Scots, a fact they must be made aware of.

Based on my observations I contend there is more at stake. The teacher combines two types of epistemic stance. In the first, she attributes of a position of knowledge to the pupils: they become, theoretically, the experts. In taking this stance, she apparently transfers the linguistic part of her authority onto the children. In the second, however, she retains the authority of attributing that knowledge to them, based on assumptions regarding the nature of Scots and the practices of her pupils. But in the absence of a linguistic standard conceived ideally as an outside source of authority, that expertise cannot be derived from their actual practices; it is instead anchored in the pupils themselves, in what she takes to be their identity-conflating expectations of place (Scottishness) and social class (working class background). This, as we will see next, gives rise to disalignment, or at least a lack of uptake on the children's part.

\section{Othering and the Assignment of Identity}

The above observations call for deeper analysis, and in particular for an explanation of why the pupils reacted with good-hearted participation yet consistently demurred with respect to taking up a Scots-speaking identity or stance throughout the lesson. I argue here that the opposition was not to Scots or to the lesson itself, but to the very process of othering under way. We see this resistance exhibited somewhat clumsily in a series of infelicitous turns towards the end of the exchanges about the poem. That moment reveals the ambiguity generated by the lack of clear status for Scots: while 
the children are construed as experts of their own language, their actual realizations fail to meet the expected level of the true vernacular which the teacher apparently has in mind (relative to the quality of the vowels discussed above, for example). Thus in reality their expertise remains limited as their answers are corrected and repaired in the interactions.

The pupils' disalignment can therefore be seen as both a rejection of the identity work at play as well as of the claims of their expertise, in order to conform to the more usual school expectation that linguistic authority lies not within themselves but in an external source, usually embodied by the teacher. In the next excerpt, in which the pronunciation of the word "washing machine" is discussed, the children refuse the othering act that separates them from the teacher by contesting that she really speaks differently from them.

\section{Excerpt 7}

1 Teacher so there you go usually / whereas / James and I had a big discussion about

2 how I've got a different accent from you and I may use some words that are like 3 Glasgow slang [but I would

4 Pupil [yeah you use some Ellrig ${ }^{6}$ as well / you say Ellrig words like 5

6 Teacher I don't say washing [wa $\mathrm{nn}$ ] machine but I'd say washing [wD $\mathrm{n} n$ ] machine but 7 there's other words that I'm saying that you wouldn't say only because maybe 8 where I've grown up or where I've stayed

Many elements intersect in this extract. First in terms of linguistic categories, the borders between slang and language are blurred and students and teacher compete over the definition of what might count as legitimate Scots beyond slang. The terms that the pupil suggests as being local ("important") as opposed to nonlocal ("crucial") are also puzzling but they suggest that reasons exist for the pupils to challenge the teacher's claims to speak differently. In fact, my observations suggest that geographic distinctions are not relevant for the pupils, for whom speech falls under the categories of either "slang" or "proper." To them, the teacher more likely falls under the latter category, while their own everyday interactions would fall under the former.

A second instance of implicit contestation (or lack of uptake) has been seen in Excerpts 5 and 6, where the pupils failed to produce the expected realizations of words (washing machine, pocket) or phrases. Their reactions suggest that they are caught in the difficult position of responding to implicit teacher expectations behind her instructions to pronounce words "as they would normally." The lack of mutual understanding is thus not due to a cultural or language gap but is arguably related to the hazy nature of Scots and how it is reflected in the teacher's instructions. In Excerpt 8 below the teacher attempts to summarize her main point; the use of pronouns again points to a facade of pupil-teacher alignment that conceals resistance or lack of understanding over the Scots issue:

\section{Excerpt 8}

1 Teacher how would you feel if you were in school and the teacher was correcting you all

2 the time / if you said to me [...] how would you feel in school if you said to

3 me Mrs. Brennan ah dinnae ken what you're talking aboot ${ }^{7}$ and I said WHAT do

$4 \quad$ you mean / you mean you don't understand what I'm talking about

5 Cassie yes

6 Teacher how would that make you feel if I constantly constantly corrected you / Sarah?

7 Sarah it would make me feel bad because that's the way you speak in your 8 language

9 Teacher it would make you feel bad because that's the way you speak and that's your language / would it be [...] would it make you [...] is it fair for me to correct you for the way you speak? 


\section{Pupils no}

13 Teacher no / because as Sarah said that's the way you speak / and that is the way that 14 you've been brought up

Cassie's response on line 5 indicates that she has not attended at all to the implicit connections between teacher/English and pupils/Scots the teacher has performed through code-switching. She simply responds to the content of the question. On line 7, the pronouns used by Sarah suggest that she is repeating a teacher discourse she does not fully endorse. The teacher interprets her statement as a misunderstanding about whose language is in question, and repeats Sarah's statement emphasizing the "you" and "your" (lines 8-9). In doing so she implicitly positions Sarah's (pupil/Scots) language as the potential target for correction and subsequent potential stigmatization.

In the next excerpt I look at another way in which miscommunication around the Scots issue is resolved through appealing to an outer source of authority, namely myself (line 3), but at a cost: the teacher further weakens the position of Scots in contrast to English.

\section{Excerpt 9}

1 Teacher I don't say washing [wa $\int \mathrm{n}$ ] machine but I'd say washing [wp $\mathrm{n} n$ ] machine but 2 there's other words that I'm saying that you wouldn't say only because maybe 3 where I've grown up or where I've stayed but it's all it's what we were saying $4 \quad$ James isn't it we decided that where can you say what is scots and what's not scots it's a very big big debate / what's a debate Fiona? ///

The teacher thus changes footing and concedes the hazy nature of Scots. The call for an external source of authority temporarily takes away authority from the pupils, reinforcing her lack of control over the issue of how to define Scots, but also enabling her to move on to the next stage of the lesson.

\section{Discussion: Attributing and Disattributing Authority}

In this section I discuss the implications of the analysis above in terms of what it means to introduce nonstandard speech in schools while also claiming the "language" label.

Much of the above can be read in terms of circulation of authority, and in terms of its attribution and disattribution. At first, authority is transferred to the pupils according to the principles of the Scots language program followed in the school: they are the experts of their language; their pronunciation is thus legitimate. Yet, faced with the children's apparent resistance or a lack of uptake of that idea, the teacher adopts a different epistemic stance: the knowledge upon which the authority is based is no longer located within the children, but temporarily shifted back to the teacher through the mediation of the external researcher, i.e., myself. She thus differentiates between two types of knowledge, the knowledge of Scots (as a competence) and the knowledge of what Scots is. The latter, however, is not predicated upon the former, hence several instances of hesitation over the definition of Scots.

The transfer of expertise is operated not only by connecting Scots as a legitimate language with the children's vernacular, but also with who they are as individuals through a process of othering. In other words, the teacher shifts the language program's legitimizing of actual (and potentially variable) language use to that of (essentialized and invariable) identity. She transforms the program's standpoint that "what you speak is in fact Scots" to "this is the way you speak, so don't be what you are not," and finally imposes a linguistic model upon them that is connected to what she takes to be the pupils' identity. Consequently, defining Scots remains an elusive task: it lies both in what the children are supposed to speak, as well as in the teacher's assumptions of what it consists of-all of which constitute unspoken criteria throughout the interaction. 
The discursive linkage of language with identity at work in the interactions above is far from anecdotal. In fact it is arguably one of the only resources the teacher is left with to justify her being divested of the linguistic authority she usually conveys: in the absence of standard language, the authority located in it moves to other locations, in this case within the children themselves, in their identity. Conversely, in the case of standard languages the authority to legitimize language derives prototypically from an outer source (literature, linguistic academies, dictionaries, etc.). Authority thus theoretically derives from the legitimate institution that backs it, most often the state. Standards, ideally, are thus meant to belong to everyone and anyone, irrespective of what group they might otherwise see themselves as belonging to, thus erasing identity and concealing the mechanisms of linguistic authority.

Formulating the question of Scots in terms of identity raises a number of questions: who really speaks the language, and who may be considered a speaker? Are all types of Scots really equally legitimate? How is distance with English evaluated and rated, and by whom? Asking who may speak the language (legitimate speakers) raises the question of who may not. To the extent that speakerhood is linked with "natural" and "native" acquisition, the very possibility of its being learned is called into question. That is, while "language" can be acquired, the localization of "dialect" within personal identity renders its acquisition much more problematic, and requires the association of new language skills as well as new behavioral, cultural and identity reflexes. Herein lies all the ambiguity of the approach combining assets of language (status) and dialect (linguistic indefiniteness, i.e., a lack of circumscribing criteria allowing for freedom on the one hand but also insecurity).

Should Scots then be defined in terms of the Scottishness of its speakers, rather than according to an explicit linguistic norm (as Macleod suggests in the quotation referred to above)? What, then, of pupils who come from outside Scotland? The Scots language movement is very careful in framing its narrative in terms of inclusiveness, but as we have seen, this teaching strategy entails children being homogenized as all being speakers of Scots. It leaves little room for learning (and therefore integration) since there is no clear definition of what is to be learned.

"Speaking the way one speaks naturally" thus always comes with covert expectations of what this entails and means. The absence of a standard might proceed from generous ideas, but it generates unexpected and unforeseen consequences that must be addressed somehow by teachers. In the present case, the teacher resolves this contradiction by calling on what she perceives to be the children's speech and connects it with identity. In doing this, she nevertheless locks them into an essential and homogenous identity, and falls back on covert or external sources of authority to resolve the predicaments caused by the very linguistic model she follows. Linguistic authority does not simply wane when the teacher is divested of it. It circulates, moving to unexpected loci.

\section{Conclusion}

In this article, I have sought to analyze one instance where nonstandard/ nonstandardized language is used in education, initially to promote literacy skills. The approach to language I illustrate was theorized and advocated by an external body-a Scots language publisher-and this particular instance was representative of several other moments I witnessed on the ground. The publisher's endeavor itself was ambitious and generous, and aims at people and practices rather than at language as an autonomous code, all things that linguistic anthropologists are likely to feel at home with.

However, in the course of my argumentation I have shown that the absence of a standard, understood both as a shared representation of language and as a model, generates unease on the part of the teacher: she finds herself assigning specific stances and linguistic behaviors to her pupils, relying on her own inexplicit assumptions regarding the nature of Scots and is faced with their tranquil but consistent demurral 
in so doing. This amounts to an othering them as speakers of Scots within a broader narrative of Scots as an incomplete language: as something associated with the pupils rather than with her and ultimately, as a code that contrasts with the legitimate language of the school. In other words she construes English as a full language, a model against which other practices are to be evaluated, and herself as a speaker of English vs. them as natural speakers of Scots-and not, in that lesson at least, explicitly as bilinguals. As a consequence, the issue of students' legitimacy as speakers of English remains unspecified.

Finally, I reach the conclusion that linguistic authority in the classroom becomes volatile in the absence of standard language, and circulates from the teacher to the pupils. I am not suggesting that this should be avoided in the name of respect for traditional authority; what I am proposing is that this situation is an unforeseen consequence of the language program, and as such, in the conditions I described, one that destabilizes the classroom environment. Linguistic authority is constitutive of schools as educational settings, central not only to the ways teachers but also pupils behave and are expected to behave. Other types of regimes of authority are available, in particular in contexts where polynomic standards are implemented (Jaffe 2005), but they require all members of the educational community to reflect upon the consequences of the types of principles which they are willing to engage with in terms of language and education. The teacher's authority in matters of language cannot merely be dispensed with, at least not without thinking of potential consequences for each of the parties involved. In the present case, it appeared to become embedded in a particular narrative of the pupils' identity, generating a number of questions as to who is entitled to speak Scots or not, and what it might take to become an authorized speaker. Teachers and pupils are left to negotiate the nature of Scots, a daunting and in fact impossible task.

Scots is consequently left to combine haphazardly elements of "dialect" (humor, a direct sense of place) and elements of "language" (authority, legitimacy) in ways that ultimately both disfavor the forms of speech that were meant to be valorized, and that lock the pupils in an identity as speakers of these forms. Given the absence of explicit rules for usage, teaching and evaluation, and bearing in mind the role of schools as key sites for the definition of what counts as knowledge, the border between what counts as legitimate Scots (or, for that matter, legitimate slang) or gibberish ultimately relies on covert, inexplicit rules which are left to the pupils to make sense of.

Consequently, this study also supports a point hinted at by James Milroy (preface to Joseph 1987) that a standard language is not merely a dialect on a par with other otherwise equal dialects. Standard and nonstandard types of language are entrenched in distinct types of sources of authority. The authority conveyed (in principle) by standards is one that is not rooted in ethnicity, identity or localized forms of belonging, but in the public institutions associated with the emergence of Nation-states, however much this might conceal the connection of these linguistic forms with particular social classes. Therein lie the purported claims to neutrality of standard languages, and the ambiguity of Scots: can its advocates claim language status on a par with English while relinquishing claims to what makes a language in the current linguistic ideological regime?

\section{Transcription Conventions}

[

/

//

///

underlined

a:

CAPITAL overlapping speech

1 second break

2 second break

3 second or longer break

emphasis

lengthened vowel

louder occurrence 
I did not seek to represent any type of code switching in the excerpts, as this would have implied making choices as to the definition of Scots.

\section{Notes}

Acknowledgments. This paper was written during a stay at California State University Long Beach, funded by a Leiv Eiriksson scholarship from the Research Council of Norway. It was also partly supported by the Research Council of Norway through its Centers of Excellence funding scheme, project number 223265. Finally, it is a contribution to the STANDARDS project (Standardizing minority languages, chaired by Pia Lane, project number 213831), funded by the Research Council of Norway and the University of Oslo. I am much indebted to Verónica Pájaro, Janet Connor, and Alexandra Jaffe for their insightful comments on an earlier draft of this paper.

1. For further analyses on the topic, the reader is directed to Dossena (2005), McArthur (1998), McClure (2008), or Unger (2013). There are countless other volumes or articles on the subject.

2. Scotland's census website: http://www.scotlandscensus.gov.uk/documents/census results/release2a/scotland/QS212SC.pdf [accessed March 21, 2014].

3. A view which John M. Tait (2013) calls "Robertsonianism" after James Robertson, a prominent Scottish novelist, who argues that Scots is to be defined as what people speak in Scotland. This view enables him to consider it the majority language in Scotland.

4. Available online: http://www.educationscotland.gov.uk/resources/k/kistscots language/introduction.asp [consulted February 3, 2015].

5. The full text of the poem is available online on the Scottish government's education website: http://www.educationscotland.gov.uk/resources/k/kistscotslanguage/texts/ lamentforalostdinnerticket/index.asp [accessed February 3, 2015].

6. The name of the town where the school is located has been changed.

7. Translation: I don't know what you're talking about.

\section{References}

Aitken, A. J.

1990 The Good Old Scots Tongue: Does Scots Have an Identity? In Minority Languages Today. Einar Haugen, J. Derrick McClure, and Derrick S. Thomson, eds. Pp. 72-90. Edinburgh: Edinburgh University Press.

Billiez, Jacqueline, and Patricia Lambert

2008 Autour de "savoirs" sur les langues dans une classe de seconde professionnelle. In Conscience du plurilinguisme: pratiques, représentations et interventions. Michel Candelier, Gina Ioannitou, Danielle Omer, and Marie-Thérèse Vasseur, eds. Pp. 79-91. Rennes: Presses Universitaires de Rennes.

Bonacina-Pugh, Florence

2013 Categories and Language Choice in Multilingual Classrooms: The Relevance of "Teacher-hood." Language and Education 27(4):298-313.

Cheshire, Jenny, Viv Edwards, Henk Münstermann, and Bert Weltens, eds.

1989 Dialect and Education. Clevedon \& Philadelphia: Multilingual Matters.

Collins, James

1988 Language and Class in Minority Education. Anthropology \& Education Quarterly 19(4):299-326.

Costa, James

2010 Language, Ideologies, and the "Scottish Voice." International Journal of Scottish Literature 7. http:/ / www.ijsl.stir.ac.uk/issue7/costaOP.htm, accessed March 22, 2014.

2014 Must We Save the Language? Children's Discourse on Language and Community in Provençal and Scottish Language Revitalisation Movements. In Endangered Languages: Beliefs and Ideologies in Language Documentation and Revitalisation. Peter K. Austin and Julia Sallabank, eds. Pp. 195-214. Proceedings of the British Academy. Oxford: Oxford University Press/British Academy.

Coupland, Nikolas

2003 Sociolinguistic Authenticities. Journal of Sociolinguistics 7(3):417-431.

Dossena, Marina

2005 Scotticisms in Grammar and Vocabulary. Edinburgh: Birlinn. 
Eagle, Andy

2002 The Online Scots Dictionary. http://www.scots-online.org/dictionary/engscots.htm, accessed March 26, 2014.

Fitt, Matthew

1998 Scots Language in the Classroom: Viewpoint III. In The Scots Language: Its Place in Education. Liz Niven and Robin Jackson, eds. Pp. 93-98. Dundee: In·House.

Görlach, Manfred

1996 And Is It English? English World-Wide 17(2):153-174.

Heller, Monica, and Marilyn Martin-Jones

2001 Introduction: Symbolic Domination, Education and Linguistic Difference. In Voices of Authority: Education and Linguistic Difference. Monica Heller and Marilyn Martin-Jones, eds. Pp. 1-28. Westport: Ablex.

Jaffe, Alexandra

2005 Collaborative Literacy Practices in French and Corsican: The Ideological Underpinnings of a Bilingual Education. Crossroads of Language, Interaction, and Culture 6:328.

2009a Introduction: The Sociolinguistics of Stance. In Stance: Sociolinguistic Perspectives. Alexandra Jaffe, ed. Pp. 3-28. Oxford \& New York: Oxford University Press.

2009b Stance in a Corsican School. In Stance: Sociolinguistic Perspectives. Alexandra Jaffe, ed. Pp. 119-145. Oxford \& New York: Oxford University Press.

Jaworski, Adam, and Justine Coupland

2005 Othering in Gossip: “You Go out You Have a Laugh and You Can Pull Yeah Okay but Like ..." Language in Society 34(5):667-694.

Joseph, John Earl

1987 Eloquence and Power: The Rise of Language Standards and Standard Languages. New York: Blackwell.

2013 Alien Species: The Discursive Othering of Grey Squirrels, Glasgow Gaelic, Shetland Scots and the Gay Guys in the Shag Pad. Language and Intercultural Communication 13(2):182-201.

Labov, William

1973 The Linguistic Consequences of Being a Lame. Language in Society 2(1):81-115.

Lyall, Scott

2014 "That Ancient Self." European Journal of English Studies 18(1):73-85.

Macleod, Iseabail, and Pauline Cairns, eds.

1993 Concise English-Scots Dictionary. Edinburgh: Edinburgh University Press.

Macleod, Iseabail, Pauline Cairns, Caroline Macafee, and Ruth Martin, eds. 1999 Scots Thesaurus. Edinburgh: Polygon \& Scottish National Dictionary Association.

McArthur, Tom

1998 The English Languages. Cambridge: Cambridge University Press.

McClure, John Derrick

1979 Scots: Its Ranges of Uses. In Languages of Scotland. A. J. Aitken and Tom McArthur, eds. Pp. 26-48. Edinburgh: Chambers.

1980 Developing Scots as a National Language. In The Scots Language: Planning for Modern Usage. J. Derrick McClure, A. J. Aitken, and John Thomas Low, eds. Pp. 11-44. Edinburgh: Ramsey Head Press.

1985 The Debate on Scots Orthography. In Focus on Scotland. Manfred Görlach, ed. Pp. 203-209. Amsterdam: John Benjamins.

1990 The Synthesisers of Scots. In Minority Languages Today. Einar Haugen, J. Derrick McClure, and Derrick S. Thomson, eds. Pp. 91-99. Edinburgh: Edinburgh University Press.

2008 English in Scotland. In The Cambridge History of the English Language: English in Britain and Overseas: Origins and Development. Robert Burchfield, ed. Pp. 23-93. Cambridge: Cambridge University Press.

Niven, Liz, and Robin Jackson

1998 The Scots Language: Its Place in Education. Dundee: In·House.

Preston, Dennis R.

1985 The Li'l Abner Syndrome: Written Representations of Speech. American Speech 60(4):328-336.

Purves, David

1997 MacDiarmid's Use of Scots: Synthetic or Natural? Scottish Language 16:82-87.

2002 A Scots Grammar. Edinburgh: Saltire Society. 
Robertson, James

1994 A Tongue in Yer Heid. Edinburgh: B\&W Publishing.

Saxena, Mukul, and Marilyn Martin-Jones

2013 Introduction: Multilingual Resources in Classroom Interaction: Ethnographic and Discourse Analytic Perspectives. Language and Education 27(4):285-297.

Strachan, Shane

2012 Dialects in the Modern Languages Classroom: A Bidialectal Approach. Scottish Language 29:53-78.

Tait, John Magnus

2013 Robertsonianism. https://sites.google.com/site/scotsthreip/robertsonianism, accessed March 26, 2014.

TNS-BMRB

2010 Public Attitudes towards the Scots Language. Edinburgh: Scottish Government Social Research.

Unger, Johann Wolfgang

2013 The Discursive Construction of the Scots Language: Education, Politics and Everyday Life. Amsterdam \& Philadelphia: John Benjamins.

Woolard, Kathryn Ann

2008 Language and Identity Choice in Catalonia: The Interplay of Contrasting Ideologies. In Lengua, Nación e Identidad: La Regulación del Plurilingüismo en España y América Latina. Kirsten Süselbeck, Ulrike Mühlschlegel, and Peter Masson, eds. Pp. 303-323. Frankfurt am Main \& Madrid: Vervuert \& Iberoamericana. 